\title{
MICRO-FINANCE, SELF HELP GROUPS AND WOMEN EMPOWERMENT IN HIMACHAL PRADESH: A STUDY OF LOW HILL ZONE
}

\author{
Ajay Kumar \\ Assistant prof, Department of Economics, Govt. Degree College Dhaneta (HP) \\ DOI: 10.46609/IJSSER.2020.v05i11.004 URL: https://doi.org/10.46609/IJSSER.2020.v05i11.004
}

\begin{abstract}
Development of a nation is very much dependent on the development of rural people. Today, the real problem faced by every developing country like India is the poverty. Nearly half of the available human resource in India is women. Majority of them are living in rural areas and most of them are illiterates and are below poverty line. Besides this in comparison to urban women, rural women have limited access to all kinds of resources such as education, transportation, training, financial support, availability of current information etc. but have more hidden talents, which have to be bought in to light. Hence, there is need to change their capacity to work by giving them the necessary trainings on income generating activities, bringing their talents into light, supporting them with financial facilities, giving them marketing knowledge, current information etc. which helps in increasing knowledge, enriching their skills and improve their economic status.
\end{abstract}

\section{Introduction}

Micro-finance basically aims at the self-sustainability of poor people through income generating activities but it also provides credit for consumption purpose (Das, 2003) ${ }^{1}$. The concept of Micro-Credit was formally pioneered by Mohammed Yunus, founder of Grameen Bank in 1976. An innovative scheme in rural delivery system launched by NABARD is the linking of SHGs of the poor with banks and bulk lending through NGOs. NABARD provides policy guidelines technical and promotional support mainly for capacity building of NGOs and SHGs, the exposure training to banks/NGOs having potential and in promoting SHGs (Christabell, 2009) ${ }^{2}$. The inability of the credit institutions to deal with the credit requirements of the poor particularly poor women in rural areas effectively has led to the emergence of the microfinance and micro credit system for the poor. In rural India, it can be seen that poor sections of the society and destitute cannot avail the credit from banks and other formal financial institutions-due to their 


\section{International Journal of Social Science and Economic Research}

ISSN: $2455-8834$

Volume:05, Issue:11 "November 2020"

inability to deposit collateral security and mortgage properly. The government sponsored poverty alleviation programmes are involved centrally and planned without participation of the local people, and therefore fail to address the needs and requirement of the poor. Lacks of participatory approach in planning and execution of these programmes result in complete failure to improve social and economic conditions of the poor masses for which they were evolved. At this point, micro financing is looked upon as an instrument that can be considered as the golden stick to generate income and employment and an important approach to poverty alleviation and enhancement of living standards, particularly of women (Verma, 2009) ${ }^{3}$. Women constitute nearly half of India's population and play an important role in social and economic development of the nation. But their role is marginalized in the context of national development. For, no country can sustain its development if it does not utilize properly its women as a productive resource. Women empowerment is regarded as a necessary condition to stabilize and in turn to have a sustainability of the development process. Empowerment of women is an active multidimensional process which enables women to realize their full identity and powers in all sphere of life. In other words, empowerment of women represents ability of women to handle responsibility to envision a better future and also to overcome the obstacles that confront them. Empowerment of women includes higher literacy level and education for women, better health care, equal ownership of productive resources and more participation in economic and Commercial sectors, improved standard of living and acquiring self-reliance, self-esteem and self-confidence. (Kittur and Shidaganal, 2010) ${ }^{4}$. The women's empowerment and eradication of poverty under micro finance schemes are made possible through the formation of Self Help Groups. A Self-Help Groups are usually informal groups whose members have a common perception of need and importance towards collective action. These groups are voluntarily associations of people with the member size of 10 to 20 . The group is basically homogeneous in terms of education, occupation, income distribution and sex composition. Self-Help Groups are necessary to overcome exploitation, create confidence for the economic self-reliance of rural poor, particularly among women who are mostly invisible in the social structure. These groups enable them to come together for a common objective and gain strength from each other to deal with exploitation which they are facing in several forms. A group becomes the basis for action and, change. It also helps building of relationship for mutual trust between the promoting organization and the rural poor to constant contact and genuine efforts (Singh, 2003) ${ }^{5}$.

Self-Help Groups are formed with the following objectives:

(a) Improve discipline among the members in developing saving habits;

(b) Saving enhance self-confidence of the individual as it is a sign of group encouragement;

(c) Income generation and gradually become self-reliant; 


\section{International Journal of Social Science and Economic Research}

ISSN: $2455-8834$

Volume:05, Issue:11 "November 2020"

(d) Development of leadership quality to realize their potentiality and self -belief;

(e) Training of members in the use of extension services and government support;

(f) Building common infrastructure for the benefit of the members (Das, 2003) .

\section{Need of the Study}

Poor need credit in small doses, frequently and that it should be made available when it is needed the most. Time and tide, wait for none. A timely loan of Rs. 500 may ensure the survival of a person in case of medical emergency, if time has run out; a bigger loan will also not bring back that person from the outer world. So, in order to cover all the poor households, particularly BPL households, there is need for providing full support by the government, financial institutions and NGOs to Self-Help Groups programme. So, for the Self-Help Groups bank linkages programmes has been much successful in achieving quantitative targets. The need of the hour is to make the programmme more qualitative that is enriching the lives of poorest of the poor in the context of globalised socio-economic environment.

\section{Research Methodology and data collection tools}

In the present study block Hamirpur in Hamirpur district has been selected purposively because Hamirpur block is relatively more developed in terms of literacy, female employment and has comparatively better performance of SHGs in comparison to other blocks (Bijhari, Bhoranj, Sujanpur, Nadaun and Taunni Devi). An empirical study was conducted with 200 self help group members. Random Sampling method was adopted.

The study is based on collection of data from both primary and secondary sources. The primary data has been collected through personal interviews and observation and secondary data through Govt. agencies responsible for formulation of groups and financial institutions like ICDS, DRDA, NGOs, Banks and NABARD.

\section{Objective}

1. To study the role of Self Help Groups in Himachal Pradesh.

2. To assess the contribution of micro-finance to the well-being of poor women in Himachal Pradesh.

\section{Sampling Procedure}

For the collection of first hand data and information, multistage purposive-cum-random sampling was adopted. Himachal Pradesh is divided into three major agro-climatic zone, namely, low hill zone, mid-hill zone and high-hill zone. 
International Journal of Social Science and Economic Research

ISSN: 2455-8834

Volume:05, Issue:11 "November 2020"

\section{a) Low Hill Zone}

The elevation of this zone ranges from an altitude of 350 metres to 950 metres above mean sea level (MSL) and this includes Hamirpur, Una and parts of Kangra, Bilaspur, Mandi, Shimla, Solan, Kullu and Sirmaur districts. These areas are very fertile and can be subjected to intensive cultivation.

\section{b) Mid Hill Zone}

It lies between 950 to 1500 metres above mean sea level. This zone comprises of parts of Solan, Sirmaur, Shimla, Kullu, Bilaspur, Mandi and Chamba districts. Although field crops are raised in this zone but it is more suitable for horticultural corps i.e. fruits and off-seasonal vegetables.

\section{c) High Hill zone}

This zone lies above the elevation of 1500 metres above the mean sea level and includes interior parts of Shimla, Kullu, Mandi, Solan, Sirmaur, Chamba and Kangra districts. This zone is good for raising forests. Because of altitude and severe winter conditions, these hills are sparsely populated. Above 3500 metres of mean sea level, Alpine zone is started which is abound in pasture lands. However, there is also a land of perpetual snows above the perpetual snow line and are without any vegetation.

From these three zones, low hill zone was selected purposively. This zone was selected for the reason that geographically, the areas of this zone are easily accessible for the purpose of implementation of development programmes and policies. Also, almost every nook and corner of this zone is connected with the roads and transportation. Hence, this zone was selected to see the position of microfinance and its socio-economic impact on the members of self-help groups.

\section{Self Help Groups in Himachal Pradesh}

The Self Help Group (SHG) movement has spread across the state and is now on a firm base. The movement has been up scaled with support in the human resources and financial products. There were 50,749 SHGs as on 30th September, 2009 operative in the state promoted by Department of Social Justice and Empowerment and various NGOs. The number of SHGs credit linked in H.P. up to the end of September, 2009 was 49,318 and 1, 124 bank branches were associated with micro credit movement. A total of 30 farmer's clubs were working as self help promoting institutions (Statistical Outline 2008-09) ${ }^{7}$. 
International Journal of Social Science and Economic Research

ISSN: 2455-8834

Volume:05, Issue:11 "November 2020"

\section{Table-1}

\section{Self Help Groups in Himachal Pradesh up to March 2010}

\begin{tabular}{|c|c|c|c|c|c|c|c|c|c|c|}
\hline \multirow[t]{2}{*}{ Districts } & \multicolumn{2}{|c|}{$\begin{array}{l}\text { No. of Groups } \\
\text { Formed }\end{array}$} & \multicolumn{2}{|l|}{ Savings } & \multicolumn{2}{|c|}{$\begin{array}{l}\text { Linked with } \\
\text { Banks }\end{array}$} & \multicolumn{2}{|c|}{ Amount of Loan } & \multirow{2}{*}{$\begin{array}{l}\text { Yet to be } \\
\text { Linked } \\
\text { with } \\
\text { Banks }\end{array}$} & \multirow{2}{*}{$\begin{array}{l}\text { No. of Haats } \\
\text { organized } \\
\text { during } \\
2009-10\end{array}$} \\
\hline & $\begin{array}{l}\text { Cumu- } \\
\text { lative }\end{array}$ & $\begin{array}{l}\text { During } \\
2009-10\end{array}$ & $\begin{array}{l}\text { Cumu- } \\
\text { lative }\end{array}$ & $\begin{array}{l}\text { During } \\
2009-10\end{array}$ & $\begin{array}{l}\text { Cumu- } \\
\text { lative }\end{array}$ & $\begin{array}{l}\text { During } \\
2009-10\end{array}$ & $\begin{array}{l}\text { Cumu- } \\
\text { lative }\end{array}$ & $\begin{array}{l}\text { During } \\
2009-10\end{array}$ & & \\
\hline Hamirpur & $\begin{array}{l}2461 \\
(9.44)\end{array}$ & $\begin{array}{c}201 \\
(10.27)\end{array}$ & $\begin{array}{c}455902 \\
80 \\
(7.4)\end{array}$ & $\begin{array}{c}790442 \\
0 \\
(8.25)\end{array}$ & $\begin{array}{l}1084 \\
(9.04)\end{array}$ & $\begin{array}{l}111 \\
(9.8)\end{array}$ & $\begin{array}{c}54190 \\
700 \\
(7.46)\end{array}$ & $\begin{array}{c}6012200 \\
(4.62)\end{array}$ & $\begin{array}{l}1377 \\
(10.1)\end{array}$ & $\begin{array}{c}19 \\
(7.54)\end{array}$ \\
\hline Bilaspur & $\begin{array}{l}1596 \\
(6.12)\end{array}$ & $\begin{array}{c}202 \\
(10.32)\end{array}$ & $\begin{array}{c}233494 \\
46 \\
(3.79) \\
\end{array}$ & $\begin{array}{c}727461 \\
1 \\
(7.59) \\
\end{array}$ & $\begin{array}{l}996 \\
(8.31)\end{array}$ & $\begin{array}{c}64 \\
(5.6)\end{array}$ & $\begin{array}{c}39915 \\
563 \\
(5.49)\end{array}$ & $\begin{array}{c}6148500 \\
(4.73)\end{array}$ & $\begin{array}{l}600 \\
(4.4)\end{array}$ & $\begin{array}{c}14 \\
(5.56)\end{array}$ \\
\hline Kullu & $\begin{array}{l}1507 \\
(5.78)\end{array}$ & $\begin{array}{c}103 \\
(5.26)\end{array}$ & $\begin{array}{c}193548 \\
17 \\
(3.14)\end{array}$ & $\begin{array}{c}139616 \\
3 \\
(1.46)\end{array}$ & $\begin{array}{l}958 \\
(7.99)\end{array}$ & $\begin{array}{c}62 \\
(5.5)\end{array}$ & $\begin{array}{c}30443 \\
500 \\
(4.19)\end{array}$ & $\begin{array}{c}4969200 \\
(3.82)\end{array}$ & $\begin{array}{l}549 \\
(4.02)\end{array}$ & $\begin{array}{c}24 \\
(9.52)\end{array}$ \\
\hline L\&S & $\begin{array}{c}60 \\
(0.23)\end{array}$ & - & $\begin{array}{c}775400 \\
(0.13)\end{array}$ & $\begin{array}{c}77097 \\
(0.08)\end{array}$ & $\begin{array}{c}11 \\
(0.09)\end{array}$ & - & $\begin{array}{c}48200 \\
0 \\
(0.06)\end{array}$ & - & $\begin{array}{c}32 \\
(0.23)\end{array}$ & - \\
\hline Mandi & $\begin{array}{l}4855 \\
(18.60)\end{array}$ & $\begin{array}{c}180 \\
(9.19)\end{array}$ & $\begin{array}{c}105627 \\
369 \\
(17.2)\end{array}$ & $\begin{array}{c}176629 \\
19 \\
(18.4)\end{array}$ & $\begin{array}{l}2358 \\
(19.7)\end{array}$ & $\begin{array}{l}377 \\
(33)\end{array}$ & $\begin{array}{c}18752 \\
7940 \\
(25.83)\end{array}$ & $\begin{array}{c}2548787 \\
(19.6)\end{array}$ & $\begin{array}{l}2497 \\
(18.31)\end{array}$ & $\begin{array}{c}104 \\
(41.3)\end{array}$ \\
\hline Una & $\begin{array}{l}1840 \\
(7.06)\end{array}$ & $\begin{array}{c}104 \\
(5.31)\end{array}$ & $\begin{array}{c}500662 \\
80 \\
(8.13)\end{array}$ & $\begin{array}{c}106400 \\
20 \\
(11.1)\end{array}$ & $\begin{array}{c}797 \\
(6.65)\end{array}$ & $\begin{array}{l}45 \\
(4)\end{array}$ & $\begin{array}{c}34985 \\
406 \\
(4.82)\end{array}$ & $\begin{array}{c}3349000 \\
(2.57)\end{array}$ & $\begin{array}{l}1043 \\
(7.65)\end{array}$ & $\begin{array}{c}10 \\
(3.97)\end{array}$ \\
\hline Solan & $\begin{array}{l}2390 \\
(9.17)\end{array}$ & $\begin{array}{c}178 \\
(9.09)\end{array}$ & $\begin{array}{c}692415 \\
67 \\
(11.2) \\
\end{array}$ & $\begin{array}{c}166611 \\
2 \\
(17.4) \\
\end{array}$ & $\begin{array}{l}1347 \\
(11.2)\end{array}$ & $\begin{array}{l}117 \\
(10)\end{array}$ & $\begin{array}{c}15972 \\
6320 \\
(22)\end{array}$ & $\begin{array}{c}3089527 \\
2 \\
(23.8) \\
\end{array}$ & $\begin{array}{l}1043 \\
(7.65)\end{array}$ & - \\
\hline Kangra & $\begin{array}{l}4616 \\
(17.7)\end{array}$ & $\begin{array}{c}329 \\
(16.8)\end{array}$ & $\begin{array}{c}712882 \\
87 \\
(11.6) \\
\end{array}$ & $\begin{array}{c}127238 \\
19 \\
(13.3) \\
\end{array}$ & $\begin{array}{l}1878 \\
(15.7)\end{array}$ & $\begin{array}{c}66 \\
(5.8)\end{array}$ & $\begin{array}{c}94553 \\
616 \\
(13.03) \\
\end{array}$ & $\begin{array}{c}1372355 \\
8 \\
(10.6) \\
\end{array}$ & $\begin{array}{l}2738 \\
(20.08)\end{array}$ & $\begin{array}{c}35 \\
(13.9)\end{array}$ \\
\hline Chamba & $\begin{array}{l}1517 \\
(5.82)\end{array}$ & $\begin{array}{c}226 \\
(11.54)\end{array}$ & $\begin{array}{c}158226 \\
436 \\
(25.7) \\
\end{array}$ & $\begin{array}{c}591507 \\
2 \\
(6.18) \\
\end{array}$ & $\begin{array}{l}358 \\
(2.99)\end{array}$ & $\begin{array}{c}28 \\
(2.5)\end{array}$ & $\begin{array}{c}15175 \\
310 \\
(2.09)\end{array}$ & $\begin{array}{c}3198140 \\
(2.46)\end{array}$ & $\begin{array}{c}1159 \\
(8.5)\end{array}$ & - \\
\hline Shimla & $\begin{array}{l}2211 \\
(8.48)\end{array}$ & $\begin{array}{c}149 \\
(7.61)\end{array}$ & $\begin{array}{c}305846 \\
64 \\
(4.97)\end{array}$ & $\begin{array}{c}485492 \\
0 \\
(5.07)\end{array}$ & $\begin{array}{c}642 \\
(5.36)\end{array}$ & $\begin{array}{c}40 \\
(3.5)\end{array}$ & $\begin{array}{c}18713 \\
328 \\
(2.57)\end{array}$ & $\begin{array}{c}2476419 \\
(1.9)\end{array}$ & $\begin{array}{l}1087 \\
(7.97)\end{array}$ & $\begin{array}{c}10 \\
(3.97)\end{array}$ \\
\hline Sirmaur & $\begin{array}{l}2665 \\
(10.2)\end{array}$ & $\begin{array}{c}230 \\
(11.75)\end{array}$ & $\begin{array}{c}356647 \\
02 \\
(5.79) \\
\end{array}$ & $\begin{array}{c}887556 \\
6 \\
(9.27) \\
\end{array}$ & $\begin{array}{l}1279 \\
(10.7)\end{array}$ & $\begin{array}{l}200 \\
(18)\end{array}$ & $\begin{array}{c}74698 \\
800 \\
(10.29) \\
\end{array}$ & $\begin{array}{c}2874451 \\
2 \\
(22.1) \\
\end{array}$ & $\begin{array}{l}1413 \\
(10.36)\end{array}$ & $\begin{array}{c}30 \\
(11.9)\end{array}$ \\
\hline Kinnaur & $\begin{array}{c}359 \\
(1.38)\end{array}$ & $\begin{array}{c}56 \\
(2.86)\end{array}$ & $\begin{array}{c}601313 \\
7 \\
(0.98)\end{array}$ & $\begin{array}{c}180334 \\
6 \\
(1.88)\end{array}$ & $\begin{array}{c}278 \\
(2.32)\end{array}$ & $\begin{array}{c}26 \\
(2.3)\end{array}$ & $\begin{array}{c}15492 \\
600 \\
(2.13)\end{array}$ & $\begin{array}{c}5070000 \\
(3.9)\end{array}$ & $\begin{array}{c}98 \\
(0.72)\end{array}$ & $\begin{array}{c}6 \\
(2.38)\end{array}$ \\
\hline Total & $\begin{array}{c}26077 \\
(100)\end{array}$ & $\begin{array}{l}1958 \\
(100)\end{array}$ & $\begin{array}{c}615782 \\
393 \\
(100) \\
\end{array}$ & $\begin{array}{c}957890 \\
80 \\
(100) \\
\end{array}$ & $\begin{array}{c}11986 \\
(100)\end{array}$ & $\begin{array}{l}1136 \\
(100)\end{array}$ & $\begin{array}{c}72590 \\
5083 \\
(100)\end{array}$ & $\begin{array}{c}1300746 \\
71 \\
(100) \\
\end{array}$ & $\begin{array}{c}13636 \\
(100)\end{array}$ & $\begin{array}{l}252 \\
(100)\end{array}$ \\
\hline
\end{tabular}

Source: Social Justice and Empowerment Department (Kasumpti) Shimla, 2009-10.

Note: (-) Data not available

Figures in the parenthesis denote percentage 
International Journal of Social Science and Economic Research

ISSN: 2455-8834

Volume:05, Issue:11 "November 2020"

\section{Result and Discussion}

In this section, the second objective about the well-being of the poor women in terms of savings, credit availed, loan used for multiple purposes, income generating activities and self confidence of the members are analyzed.

Table -2 saving mobilized by the members

\begin{tabular}{|c|c|c|}
\hline Saving amount in (Rs) & No of members & per cent of total \\
\hline Less than 1000 & 65 & 32.5 \\
\hline $1001-2000$ & 105 & 52.5 \\
\hline $2001-3000$ & 25 & 12.5 \\
\hline More than 3000 & 05 & 2.5 \\
\hline Total & 200 & 100 \\
\hline
\end{tabular}

Source: Field study

Above table indicates that majority (about 53 per cent) of the members saved between Rs ' 1001 to 2000' and least (about 3 per cent) of the members saved 'more than Rs 3000'. All members reported savings with the group. SHGs were able to develop savings habits among the members. Regular, savings of Rs. 10 is compulsory in all the SHGs. Savings is collected at the time of weekly meetings and all the members were issued a passbook. These weekly savings are deposited in nearby bank in the account of the group and have accumulated over a period of six months.

Table $\mathbf{- 3}$ credit availed by the members

\begin{tabular}{|c|c|c|}
\hline Amount of credit (Rs) & No of members & per cent of total \\
\hline $500-10000$ & 85 & 42.5 \\
\hline $10001-20000$ & 55 & 27.5 \\
\hline $20001-30000$ & 45 & 22.5 \\
\hline $30001-40000$ & 15 & 7.5 \\
\hline Total & 200 & 100 \\
\hline
\end{tabular}

Source: Field survey

SHGs were emerged as the major source of credit for its members. Table- 3 indicates that majority of the members have taken loans between 'Rs 500 to 10000 ' and least of the members between 'Rs 30001 to 40000'. Loans are provided to meet the needs of the members for various purposes such as, to meet immediate consumption needs, treatment of illness, payment of children's school fees etc. (Table 4). The loan amount varied from Rs. 500 to Rs. 40,000. In the 
International Journal of Social Science and Economic Research

ISSN: 2455-8834

Volume:05, Issue:11 "November 2020"

case of SHGs, a member can apply for a loan as soon as $\mathrm{He} / \mathrm{she}$ has completed the minimum required period of savings of six months.

Table -4 Loan used by the members for multiple purposes

\begin{tabular}{|c|c|c|}
\hline Purpose of loan & No of members & per cent of total \\
\hline Consumption purpose & 95 & 47.5 \\
\hline Asset creation & 125 & 62.5 \\
\hline Housing improvement & 85 & 42.5 \\
\hline Redemption of old debts & 80 & 40.0 \\
\hline Total & 200 & 100 \\
\hline
\end{tabular}

Source: Field survey

Only a simple application on a plain paper or an oral presentation of the purpose and amount of loan, need to be submitted. SHGs priorities the loan purposes like meeting medical expenses, children's school fee, and redemption of old debts, etc. (Table 4). Nearly 48 per cent of the respondents availed loan for meeting consumption needs and another 42.5 per cent for housing improvement. Majority of the members (about 63 per cent) availed loan for asset creation. The loan amount needs to be repaid in equal weekly installments. It is interesting to note that the members make it a point to repay the loan in time so that they are eligible for a second loan only on repayment of the first loan without default. Almost all the members except unemployed members reported that they are able to repay the loan amount out of their own income from wage employment or income from self employment activities.

Table-5 shows the income generation activities undertaken by the members for various purposes. The members were encourager under SHGs to set up their own income generating activities. Dairying, Bag making and tailoring were found to be the major economic activities undertaken by the members. Members were availed loan for dairying under Swamajayanti Gram Swarozgar Yojana (SGSY), a Government sponsored poverty alleviation scheme.

Table -5 Income generation activities undertaken by the members

\begin{tabular}{|l|c|c|}
\hline \multicolumn{1}{|c|}{ Type of activity } & No of members & per cent of total \\
\hline Dairying & 95 & 47.5 \\
\hline Tailoring & 125 & 62.5 \\
\hline Bag Making & 85 & 42.5 \\
\hline Bamboo making & 80 & 40.0 \\
\hline Total & 200 & 100 \\
\hline
\end{tabular}

Source: Field survey 
International Journal of Social Science and Economic Research

ISSN: 2455-8834

Volume:05, Issue:11 "November 2020"

Under this scheme, a group consisting of 10 members is financed with one to two lakh of rupees for the construction of shed and purchase of cow.

Table -6 Self- confidence level of the members

\begin{tabular}{|c|c|c|c|c|}
\hline \multirow{2}{*}{ Particulars } & \multicolumn{2}{|c|}{ Pre- Self Help Group } & \multicolumn{2}{c|}{ Post -Self Help Group } \\
& \multicolumn{2}{|c|}{ Contribution } & Increased greatly & No change \\
& Yes & No & & 40 \\
\hline Feed family & 160 & 40 & 110 & 22 \\
\hline Educate children & 80 & 120 & 80 & 40 \\
\hline Take Major decisions & 115 & 85 & 100 & 15 \\
\hline Resolve conflicts & 28 & 172 & 22 & 8 \\
\hline Leadership & 35 & 165 & 15 & \\
\hline
\end{tabular}

Source: Field survey

The respondents expressed high level of self-confidence because of their ability to contribute to their household, and their ability to freely interact with other members of the community. They also expressed the feeling that their status within the family also improved because of association with the group. Majority of the members now experience better treatment in their family than that of pre-NHG situation. It was significant to note that most of the members reported that they now feel respected in their family because of the fact that they were able to contribute something of value to their household either in terms of loans, or contribution to household income (Table 6).

\section{Conclusion}

The foregoing discussion on its beneficiaries revealed positive changes in the level of living of the members in terms of savings, credit and utilization of loan for various purposes and income generating activities and self-confidence of the members. Majority of the members now experience better treatment in their family than that of pre-SHG situation. It was significant to note that most of the members reported that they now feel respected in their family because of the fact that they were able to contribute something of value to their household.

\section{References}

1. Das, Sabyasachi, "Self-Help Groups and Micro Credit: Synergic Integration", Kurukshetra, August 2003, pp. 27-29.

2. Christabell, P.J. (2009). Women Empowerment Through Capacity Building The Role Of Micro-Finance, New Delhi: Concept Publishing Company, p. 91. 
3. Verma, Renu, "Microfinance and Empowerment of Rural Women", Kurukshetra, 56(11), September 2008, p. 4.

4. Kittur A.T. and Shidaganal M.V., "Stree Shakti SHGs and Empowerment of Women in Haveri District Karnataka", Third Concept, March 2010, pp. 50

5. Singla, Madan Lal, "Microfinance and Economic Development in India", Growth and Challenges", International Journal of Research in Finance and Marketing, volume 4, issue 3, March, 2014.

6. Poonarsi, T. et al., "Impact of Microfinance Innovation in pushing back rural poverty in Tamil Nadu”, Indian Journal of Agricultural Economics Vol.66, No.3, July-Sept, 2011.

7. Singh, Raj Om, "Role of N.G.O.s. in Fostering Self-Help Groups: A Case Study of Myrada, Kurukshetra, February 2003, p. 34. 